\title{
CMVpp65/gB Plasmid Vaccine ASP0113
}

National Cancer Institute

\section{Source}

National Cancer Institute. CMVpp65/gB Plasmid Vaccine ASP0113. NCI Thesaurus. Code C111903.

A poloxamer-formulated, bivalent DNA vaccine containing two plasmids encoding both the human cytomegaloviral (CMV) tegument phosphoprotein 65 (pp65), a major internal matrix protein, and glycoprotein $\mathrm{B}(\mathrm{gB})$, an important $\mathrm{CMV}$ component responsible for attachment and entry into cells, with potential immunostimulatory properties. Upon intramuscular injection of CMVpp65/gB plasmid vaccine ASP0113, the expressed proteins may activate the immune system to mount both cellular and humoral immune responses ag ainst CMV-positive cells. This results in cell lysis of CMV-infected cells and prevents both viral replication and the development of CMV disease. This vaccine also provides active immunization and protective immunity against CMV infection in CMV-negative patients exposed to infected donor cells or tissues in transplant recipients. CMV infection can cause serious complications in patients receiving either allog eneic hematopoietic cell transplants (HCT) or solid organ transplants. The poloxamer-based delivery system enhances DNA delivery. 